\title{
SATAVUOTIAS SIVISTYS
}

$\mathbf{M}$ illainen Suomen tulisi olla täyttäessään 100 vuotta ja mihin suuntaan Suomea tulisi kehittää lähestyttäessä vuotta 2017? Näihin kysymyksiin on yrittänyt löytää vastausta opetusministeriön nimeämä asiantuntijaryhmä, joka on viime vuoden lopulla ilmestyneessä mietinnössään Kansallinen sivistysstrategia tehnyt ehdotuksen sivistyspolitiikan perustaksi.

Ensimmäisenä aikuiskasvatustieteilijän mielenkiinnon herättää asiantuntijaryhmän kokoonpano. On luonnollista, että sivistystä koskeva huippuasiantuntemus löytyy opetusministeriön virkamiehiltä. Muut kuusi jäsentä ovat oppineita yliopistoista. He edustavat luotettavaa, viime vuosina kaikissa mahdollisissa työryhmissä ja seminaareissa koeteltua huipputietämystä ja - sivistystä. Mannermaat, niiniluodot, pulliaiset ja venkulat vilahtelevat sanavalmiina ja selkeinä asiantuntijoina lähes kaikissa valtakunnan asioita koskevissa kysymyksissä.

Mutta missä ovat työryhmän kasvatustieteilijät ja sivistyslaitosten ja -järjestöjen edustajat? Eikö heillä ole mitään annettavaa pohdittaessa inhimillisten kykyjen, taitojen, tietojen, asenteiden ja arvojen jatkuvaa ylläpitoa ja kehittämistä? Eikö meidän professoreillamme tai kentän edustajilla ole mitään käyttöä valtakunnallista sivistyspolitiikkaa luotaessa? Eikö sivistysjärjestöillämme ole lainkaan luottamusta ministeriössä?

$\mathbf{R}$ yhmän kokoonpano takaa asiantuntevan, viimeistellyn ja yllätyksettömän raportin toimintaympäristön muutoksista, sivistyksen muuttuvasta asemasta, kehittymisen strategioista sekä kehittymisnäkymistä 90-luvulla. Kestävä kehitys, toiminnan verkostuminen, kansainvälistyminen, siirtyminen tietointensiiviseen yhteiskuntaan ja osaamiskeskeiseen toimintatapaan sekä työn ja vapaa-ajan erojen häviäminen ovat helposti hyväksyttäviä toimintaympäristön muutoksia.

Aikuiskasvatuksen kannalta tärkeää pohdintaa on kansainvälisen toimintaympäristön muu- tosta ja tietoon nojaavaa yhteiskuntaa koskevissa osissa. Tiedon kasvava merkitys sekä vapaaajan että työelämän kannalta on merkittävää aikuisten koulutuspalveluja kehitettäessä. Ns. tietointensiivisten palvelujen ja telekommunikaatioteknologian kehittyminen ja huippuosaamista edellyttävien alojen kasvu Suomessa tarjoaa mielenkiintoisia haasteita.

Civistyksen uutta asemaa koskevassa osassa Sheijastuu vahvasti asiantuntijaryhmän kokoonpano. Korkeakoululaitos ja tiede ovat saaneet erityisaseman 1990-luvun ydinkysymysten joukossa. Korkeat kansainväliset standardit, vireät akateemisen tutkimuksen ja opetuksen keskukset muodostuvat komitean mukaan yhteiskunnan vahvoiksi kilpailueduiksi yhdentyvässä Euroopassa.

Muu aikuiskoulutus ei ole ansainnut pohdintaa. Lukiota ei pidetä riittävän korkeatasoisena mainitsematta kriteereitä ja mittauksia, mihin arviot perustuvat. Tätä argumenttia käytetään perustana yksityisten oppilaitosten synnyttämiselle. Miten tämä lisää korkeatasoisuutta?

Sivistyksen avainstrategioita esiteltäessä on tarkastelun kohteena hyvin monipuolinen ja samalla kirjava alue. Sivistyksellisistä perusoikeuksista inhimilliseen kasvuun, minikulttuurisuudesta ja kansainvälistymisestä kestävään kehitykseen, innovaatioista ja työkulttuurin muutoksista jatkuvaan oppimiseen ja kansalaistoimintaan on kehittämisstrategioiden kohteina. Useimmilla alueilla ei juurikaan löydy vastauksia, mihin suuntaan Suomea tulisi kehittää lähestyttäessä vuotta 2017. Sen sijaan esitetään kysymyksiä, joihin pitäisi saada vastaus ja joitakin yleisiä menettelytapoja, joilla asioita voitaisiin selvittää.

Moniin kysymyksiin on tarjottu ratkaisuna poliitikkojen hellimää ajatusta kansalaiskeskustelun käynnistämisestä siitä tai tästä aiheesta. Mutta miten esimerkiksi "aktivoidaan ja tuetaan kansalaiskeskustelua sivistyksen perusarvoista, kas- 
vatuksen periaatteista ja oikeudenmukaisuuden sekä globaalin, tulevaisuuteen suuntautuvan vastuun toteutumisesta". Kunnianhimoiselta kuulostaa myös ajatus, että organisaatioissa, oppilaitoksissa ja kulttuuri-instituutioissa suoritetaan arvoanalyysejä, joiden avulla lisätään arvojen tuntemusta ja arvioidaan niiden vaikutusta päätöksentekoon.

$\mathbf{K}$ oulutussuunnittelun ja -arvioinnin tutkijana odotan myös mielenkiinnolla tuloksia, joissa joku pystyy laatimaan "arvion nykyisestä ja tarvittavasta ympäristöosaamisen tasosta ja sisällöstä". Kunnianhimon puutteesta ei voi myöskään syyttää henkilöä, joka ryhtyy arvioimaan väestön ympäristöosaamisen, -arvojen ja -vastuun tilaa sekä pystyy tältä pohjalta laatimaan suunnitelmia koulutuksen ja muiden hankkeiden kehittämiseksi.

Vaativa on myös sen henkilön toimenkuva, joka laatii komitean ehdottoman "alueittaisen" (Pohjoismaat, lähialueet, Eurooppa, kaukomaat) kansainvälistymisstrategian, missä otetaan huomioon väestön liikkuvuus, matkailu, kulttuurinen ja tuotannollinen yhteistyö, tavaroiden, palveluiden, tiedon ja tutkijain vaihto, tiedonvälitys ja kansalaistoiminta".

$\mathbf{M}$ ielenkiintoa meidän jokaisen lähivuosiin tuo se, kun komitean ehdotuksen pohjalta selviää, miten osallistuvaa demokratiaa lisätään käyttämällä hyväksi yksilöiden näkemyksiä yhteiskunnallisen päätöksenteon perustana.

Vaikka kansainvälinen kilpailukyky, raha ja taloushuolet väijyvät esitysten takana esimerkiksi sivistyksen hyötyä pohdittaessa, nousee kestävä kehitys ja humanistinen ihmiskuva esille monin paikoin. Esimerkiksi verkostostrategiaa suunniteltaessa muistetaan korostaa, että verkostoja tulee kehittää inhimillisen kasvun yhteisöinä (mitä se sitten tarkoittaakin).

Tonkreettisinta antia mietinnössä on sivisI tysvaranto- ja taloustavoitteet. Esimerkiksi korkeakoulututkinnon suorittaneiden osuus on syytä kohottaa 12 prosenttiin. “Tutkimuksen osuus bruttokansantuotteesta tulisi nousta lähelle kolmea prosenttia. Kulttuurityötä tekevien työllisyystilanne tullaan pitämään todella hyvänä. Heitä tarvitaan yli 10000 lisää vuoteen 2010 mennessä. Kaikkeen koulutuspanostukseen kaivataan yksityisen sektorin rahoituksen merkittävää lisäämistä.

yös koulutuksen parissa työskentelevät 1 voivat huokaista helpotuksesta, sillä koulutukselliset perusoikeudet luvataan turvata siten, että sivistyksellinen kasvu voi jatkua. IImeisesti aikuiskoulutukseen viittaa ajatus, että koulutuksen käyttäjä joutuu itse maksamaan näistä koulutuspalveluista.

Ilolla vastaanotetaan varmasti lupaus siitä, että resursseja mitoitettaessa otetaan huomioon, että kokopäiväiseen koulutukseen osallistuu vuosikymmenen loppupuolella useita kymmeniä tuhansia koululaisia ja opiskelijoita enemmän kuin nykyisin. Jotain työnsä rasittamaa kouluttajaa saattaa hieman arveluttaa se, että korkean työttömyyden aiheuttama koulutustarve hoidetaan ensisijaisesti olemassa olevan koulutusjärjestelmän avulla sen toimintaa tehostaen.

Lukija varjellaan suurilta yllätyksiltä lueteltaessa tulevaisuuden vaateita koulutuksen toteuttajille. Aivan outoja viime vuosikymmenen keskusteluissa eivät myöskään liene esimerkiksi osaamista, aloitteisuutta ja innovaatiokykyä painottavat tavoitteet.

Cuuri usko sivistyksen ja koulutuksen merki$\checkmark$ tykseen henkii raportin loppupuolella. Jokaisen sivistystyöntekijän rintaa lämmittää ajatus, että kansallinen sivistysstrategia on keino ratkaista henkinen lama ja saattaa taloudellinen kehitys suotuisaan suuntaan. Lievä uhkauskin on jatkona: Ellei sivistykseen panosteta, lama ongelmineen syvenevät. Jos hallitus noudattaa näitä ehdotuksia sivistyspolitiikan perustana, se tulee välttymään hyvin helposti monilta yhteiskuntaa muuten uhkaavilta harmeilta (?). 